\title{
Efforts to Protect Violence in the Households during Covid-19 in Indonesia
}

\author{
Nelvitia Purba ${ }^{1, *}$, Reynaldi Putra Rosihan ${ }^{2}$, Ali Mukti Tanjung ${ }^{3}$, Rudy Pramono ${ }^{4}$, \\ Agus Purwanto ${ }^{4}$ and Mukidi ${ }^{2}$
}

${ }^{1}$ Muslim Nusantara Al Washliyah University, Indonesia

${ }^{2}$ Islam Sumatera Utara University, Indonesia

${ }^{3}$ Universitas Pembinaan Masyarakat, Indonesia

${ }^{4}$ Pelita Harapan University, Indonesia

\begin{abstract}
The social distancing appeal that the government encourages is not matched by the state's efforts to provide economic security to the community. PSBB will directly or indirectly limit the movement of the community. The teaching and learning process at schools and residents who work will be limited to working or studying at home. This limitation of activities in public spaces will have an impact on people's income, especially those in the middle to lower economy. The implementation of social distancing during the Covid-19 outbreak has increased the risk of violence against women, complicates women's economic conditions, and affirms women's social status as subordinate, or women are in a lower position than men. The formulation of the problem in this research is what is the cause of domestic violence during the covid-19 period in Indonesia, what are the prevention efforts against domestic violence during the covid-19 period. Causes of Domestic Violence During the Covid-19 Period, namely the government's appeal to the community "at home alone", causing a separate polemic for women and children, especially those who experience economic and psychological pressure at home from extraordinary isolation measures, has prompted increasing instances of reports of domestic violence, especially women who are forced to live for months in abusive relationships. causes and consequences of violence and to prevent the occurrence of violence through primary prevention programs, policy intervention and advocacy as well as information programs and supporting initiatives through all mass media TV, social networks, cell phones.
\end{abstract}

Keywords: Covid 19, Protect Violence, Households.

\section{INTRODUCTION}

Since the identification of a new type of Corona Virus (Novel Corona Virus / 2019-nCoV / COVID-19) in China in early January 2020, the virus has spread and caused hundreds of thousands of victims in various parts of the world, a virus that can cause acute respiratory distress syndrome leading to lung failure and death. The massive spread of the COVID-19 virus is currently occurring as if it was unstoppable. The delay in early identification of the spread of the virus, the weakness of protection policies for regional entry points in a country or region, the delay in systematic response of the state in overcoming the spread of the virus, to the lack of personal safety equipment and health facilities supplies, are among the several factors why the spread of this virus has become so massive in various parts of the world. Currently, the social distancing appeal that is being promoted by the government is not matched by the state's efforts to provide economic security to the community. PSBB will directly or indirectly limit the movement of the community. The teaching and learning process at

${ }^{*}$ Address correspondence to this author at the Muslim Nusantara Al Washliyah University, Indonesia; E-mail: nelvitiapurba@umnaw.ac.id

E-ISSN: 1929-4409/21 schools and residents who work will be limited to working or studying at home. This limitation of activities in public spaces will have an impact on people's income, especially those in the middle to lower economy.

According to Rohmah (2020); Purwanto (2020); Hutagalung (2020 On the other hand, until now the government has been unable to protect and guarantee the rights of its citizens who are in the current situation of the COVID-19 pandemic. For example, thousands of workers who continue to be laid off by companies in order to cut production costs of the company, the number of people who apply for loans online because their income is reduced (which later experienced terror from online lenders), drastic reduction in the income of residents who work in the informal sector, and cause a polemic in itself to women and children. The state's uncertainty in taking a stand with regard to Covid-19 raises concerns about the future of some Indonesians, especially those who experience economic and psychological pressure at home.

Secretary General of the United Nations, Antonio Guterres, revealed that the increasing social and economic pressure caused by Covid-19 also increased cases of Domestic Violence (KDRT) in women and 
girls. This statement was confirmed by Lily Puspasari, Program Management Specialist at UN Women for Indonesia. In her interview, Lily Puspasari revealed that under normal conditions, 1 (one) out of 3 (three) women in the world experience violence. WHO also discloses world facts that at least 1 (one) in 5 (five) women suffer rape or attempted rape in their lifetime. These numbers can change many times over when women spend more time at home through social distancing with the perpetrators.

The Covid-19 pandemic has changed the structure of the world of education in Indonesia even though it has entered the new normal era because the system of teaching and learning activities is still carried out online. Learning from home online does not necessarily make education costs adjust. Thus, the challenge of education in the new normal is not only the pattern of parents teaching their children at home but also the cost of education. The high cost of education, according to the Central Statistics Agency (BPS), is because the education sector experienced inflation of $3.81 \%$. In particular, the increase in the average tuition fee in Indonesia has reached $10 \%-15 \%$ per year. The cost of education is one of the biggest expenses for the community. Summarizing several domestic schools that use the international curriculum, currently the average cost of down payment for schools from Playgrounds to high school equivalents starts from IDR 8 million to IDR 40 million, maybe even more expensive than that. This fee does not include monthly fees. Although the cost of education continues to increase, Yunita Rusanti as Deputy for Distribution and Services Statistics of the BPS said that in the calculation of inflation, the increase in education inflation is mostly in private schools while state schools tend to be deflationary.

According to Nonot Yuliantoro (2020) ;Ratna Setyowati Putri (2020); Setyorini (2020); Suprapti (2020)The application of social distancing carried out during the Covid-19 outbreak has increased the risk of violence against women, made women's economic conditions difficult, and emphasized women's social status as subordinate, or women are in a lower position than men. On the other hand, women are also considered as guardians or protectors of the family (multi-role women). This indirectly places women in stressful and traumatic conditions or events. WHO even emphasizes that depression, anxiety, and other somatic symptoms in women are closely related to gender roles, stressors, and bad life experiences.
Based on the description above, the effects arising from the spread of covid-19 have led to changes in households, so this research is important to study so that it can be a solution to problems that arise from the spread of covid-19 in Indonesia.

a. What are the causes of domestic violence during the Covid-19 period in Indonesia?

b. How are efforts to prevent domestic violence during the covid-19 period?

\section{METHODS}

This research is descriptive analytical, which is a method used to describe and analyze a situation or event and explain the relationship between incident and problem to be studied. The data collection technique used in this research is library research, which is carried out to collect secondary data through an assessment of laws and regulations, literature, writings of legal experts, and lecture materials related to this research. The research about Covid-19 conducted by Rohmah (2020); Purwanto (2020); Hutagalung (2020; Fadillah (2020) ;Fatonia(2020); Supriadi (2020); Riza (2020); Affandi (2020);Ardi (2020a) Mulyadi (2017). Suryaman (2020); Nonot Yuliantoro (2020); Ratna Setyowati Putri (2020); Setyorini (2020); Suprapti (2020).

This study is based on library research (library research). Library research is a series of activities related to methods of collecting library data, reading and taking notes and processing the research material. Descriptive qualitative research specifically aims to (1). Solve actual problems faced today and (2) collect data or information to be compiled, explained and analyzed. utilize library sources to obtain research data. In this study, the authors used descriptive critical research by emphasizing the power of analysis of existing sources and data by relying on existing theories and concepts to be interpreted based on writings leading to the discussion.

There are three reasons according to Mustika Zed, why use library research only, namely First, the research problem can only be answered through library research and vice versa, it is impossible to expect the data from field research. Historical studies generally use the library research method, besides religious and literary studies also use this method. Second, literature study is needed as one of its own stages, namely preliminary studies (prelinmary research) to understand more deeply the new phenomena that are developing 
in the field or in society. Medical or biologists, for example, are forced to carry out library research to determine the nature and types of unknown viruses or bacteria. Third, library data remains reliable to answer research problems. Isn't the library a very rich gold mine for scientific research. Information or empirical data that has been collected by other people, in the form of research reports or official reports, books stored in the library can still be used by library researchers.

Four Main Characteristics of Literature Study:

1. Researchers are dealing directly with text (nash) or numerical data and not with direct knowledge from the field or eye witnesses (eyewitness) in the form of events, people or other objects.

2. Library data is 'ready to use' (ready made). This means that researchers do not go anywhere, except only face to face with source materials that are already available in the library.

3. Literature data are generally secondary sources, in the sense that researchers obtain material second hand and not original data first hand in the field.

4. The condition of library data is not limited by time and space. Researchers are dealing with static, fixed information.

\section{RESULT AND DISCUSSION}

\section{Causes of Domestic Violence During the Covid-19 Period in Indonesia}

The government's appeal for the community to "stay at home", created a separate polemic for women and children. The state's uncertainty in taking a stand with regard to Covid-19 raises concerns about the future of some Indonesians, especially those who experience economic and psychological pressure at home.

Now, these extraordinary measures of isolation have led to increasing instances of reports of domestic violence, especially women who are forced to live for months in abusive relationships. Many newspapers reported episodes of partner violence followed by dramatic abuse of their children. In addition, there is a lack of police oversight for this type of abuse due to the need to manage public order issues. The biggest risk during the Covid-19 panic is that the victim remains trapped in the house with perpetrator, with no way out or opportunity to contact outside help. The same is true for children who have been victims of violence and where isolation has prevented them from going to school and abuse is reported by teachers or friends.

During this pandemic, women have limited contact with family or friends who can provide support and protection from violence. Women suffer the most from the increased burden of housework. Closing schools increases the burden and puts additional pressure on women. Disturbances to livelihoods and ability to earn income, where previously many women worked in the informal sector, make it difficult for families to meet basic needs and services, thereby increasing mental pressure, the potential for conflict and violence.

With reduced resources, women are increasingly at risk due to economic dependence, Violators can take advantage of restrictions during the COVID-19 outbreak to prevent their partners from getting services, help, and psychosocial support from both formal and informal networks. important things such as soap or hand sanitizer Perpetrators can even control it by conveying false information about disease and stigma.

The impending domestic violence crisis of genderbased violence and child abuse and neglect, due to restrictions on movement, loss of income, isolation, overcrowding, and stress and anxiety, all place women and children at a disproportionately increased risk of harm.

\section{Prevention of Domestic Violence During the Covid- 19 Period}

Adaptations to help prevent domestic violence during this pandemic. Public health principles provide a useful framework for continuing to investigate and understand the causes and consequences of violence and to prevent violence from occurring through primary prevention programs, policy interventions and advocacy. VPA activities are guided by scientifically tested and proven principles and recommendations described in the World report on violence and health. This public health approach to violence prevention seeks to improve the health and safety of all individuals by addressing underlying risk factors that increase the likelihood of a person becoming a victim or perpetrator of violence.

This approach consists of four steps:

a. Defining problems through systematic gathering of information about the magnitude, scope, characteristics and consequences of violence. 
b. Determining why violence occurs using research to determine the causes and correlations of violence, factors that increase or decrease the risk of violence, and factors that can be modified through intervention.

c. Know what works to prevent violence by designing, implementing, and evaluating interventions.

d. Implement effective and promising interventions in a variety of settings. The effects of these interventions on risk factors and target outcomes must be monitored, and their impact and cost effectiveness evaluated.

By definition, public health aims to provide the maximum benefit to a large number of people. Programs for primary violence prevention based on a public health approach are designed to expose broad segments of the population to preventive measures and to reduce and prevent violence at the population level.

The perspectives that the VPA promotes revolve around three theoretical models: a typology of violence, a public health approach, and an ecological framework. These models guide understanding, research and action for violence prevention. Typology is a tool to help organize thinking about the types of violence and ways in which violence occurs. The public health approach offers practitioners, policymakers and researchers step-wise guidance that can be applied to program planning, policy, and inquiry. Finally, an ecological framework bridges these two models, providing a structure for understanding the context in which violence occurs and the interactions between risk factors in each of these contexts and between them. Ecological frameworks show where and how to apply public health approaches and are useful for categorizing planned or existing interventions to help understand mechanisms by which they might work.

Valeria Tullio proposes that information programs and supporting initiatives through all mass media (TV, social networks, cell phones) be increased

a. Promote reporting of violence during rare times when the perpetrator is absent;

b. Maintain online contact between teachers and educational institutions with young people, even during periods of isolation; c. Allows faster reporting by victims by sending a simple code or symbol to a dedicated toll-free number;

d. Encourage reporting of cases by family members, acquaintances, neighbors who have news or suspicions;

e. Protect victims who report violence.

Greater focus should be on families where there have been previous episodes of violence and which the authorities are already aware of. In these cases, it would be desirable to set up online social assistance services that intervene on a regular basis and are mandatory, even when there are no requests for assistance. active now, to verify the safety of the family environment. If these initiatives are adopted, they will protect victims and uncover hidden examples of domestic violence, and some crimes will be prevented altogether.

\section{CONCLUSION}

Causes of Domestic Violence During the Covid-19 Period, namely the government's appeal to the community "at home alone", causing a separate polemic for women and children, especially those who experience economic and psychological pressure at home from extraordinary isolation measures. prompting increasing instances of reports of domestic violence, especially women who are forced to live for months in abusive relationships.Prevention of domestic violence during the Covid-19 period, namely the principles of public health, provides a useful framework for continuing to investigate and understand the causes and consequences of violence and to prevent violence through primary prevention programs, policy interventions and advocacy as well as information programs and initiatives supporters through all mass media TV, social networks, cell phones. In this pandemic, the government should think about the economic and psychological conditions of the community by providing compensation and checking public health, especially with regard to community psychology. The government must be even more active in advising the community in particular to protect the family from abusive acts due to social restrictions to leave the house.

\section{REFERENCES}

Affandi, A., Sarwani, Sobarna, A., Erlangga, H., Siagian, A. O., Purwanto, A., Effendy, A. A., Sunarsi, D., Wicaksono, W., Suyatin, ., Ariyanti, E., Wahyitno, ., Manik, C. D., Juhaeri, \& 
Gunartin, (2020) Optimization of MSMEs Empowerment in Facing Competition in the Global Market during the COVID19 Pandemic Time. Systematic Reviews in Pharmacy, 11 (11), 1506-1515. doi:10.31838/srp.2020.11.213

Agus Purwant, Joko Supono, Puji Rahayu, Henri Ponda, Nur Fadilah Fatma, Mochammad Fahlevi (2020) Develop Risk and Assesment Procedure for Anticipating Covid-19 in Food Industries. Journal of Critical Reviews, 7 (15), 1991-2004. doi:10.31838/jcr.07.15.268

Agus Purwanto, Mochammad Fahlevi, Akhyar Zuniawan, Rahardhian Dimas Puja Kusuma, Heri Supriatna, Edna Maryani (2020) The Covid-19 Pandemic Impact on Industries Performance: An Explorative Study of Indonesian Companies . Journal of $\begin{array}{llll}\text { Critical Reviews, } & 7 & \text { (15), } & \text { 1965-1972. }\end{array}$ doi:10.31838/jcr.07.15.265

Agus Purwanto, Mochammad Fahlevi, Priyono Budi Santoso, Aris Setyo Radyawanto, Choirul Anwar, Utomo (2020) Exploring the Covid-19 Pandemic Impact on the Indonesian Students Performance. Journal of Critical Reviews, 7 (15), 1973-1980. doi:10.31838/jcr.07.15.266

Ardi, A., Djati, S. P., Bernarto, I., Sudibjo, N., Yulianeu, A., Nanda, H. A., \& Nanda, K. A. (2020a). The Relationship Between Digital Transformational Leadership Styles and Knowledge-Based Empowering Interaction for Increasing Organisational Innovativeness. International Journal of Innovation, Creativity and Change, 11(3), 259-277.

Ardi, A., Djati, S. P., Bernarto, I., Sudibjo, N., Yulianeu, A., Nanda, H. A., \& Nanda, K. A. (2020b). The Secret to Enhancing Innovativeness in the Digital Industry. International Journal of Innovation, Creativity and Change, 12(12), 225-243.

Fadillah, R., Surur, M., Elfrianto, ., Roziqin, A. K., Suhaili, A., Handayani, R. A., Mufid, A., Purwanto, A., Muhajir, \& Fahmi, K. (2020) The Influence of Leadership Style on Innovation Capabilities of Islamic School Teachers in Organizational Learning Perspective During Covid-19 Pandemic. Systematic Reviews in Pharmacy, 11 (7), 589-599. doi:10.31838/srp.2020.7.83

Fatonia, Nurce Arifiatib, Etty Nurkhayatic, Ela Nurdiawatid, Fidziahe, Giantoro Pamungkasf, Suhroji Adhag, Irawanh, Agus Purwantoi, Octoberry Julyantoj, Enji Azizik (2020) University Students Online Learning System During Covid-19 Pandemic: Advantages, Constraints and Solutions. Systematic Reviews in Pharmacy, 11 (7), 570-576. https://doi.org/10.1145/3442355.3433688

Gugus Tugas Percepatan Penanganan Covid-19, Risiko Kekerasan Dalam Rumah Tangga Saat Pandemi, Copyright 2020. Caroline Bradbury-Jones, Covid-19: a public health approach to manage domestic violence is needed, Copyright (C) 2020 The Author(s). Published by Elsevier Ltd. This is an Open Access article under the CC BY-NC-ND 4.0 license.

Hutagalung, L., Purwanto, A., \& Prasetya, A. B. (2020). The Five Leadership Style in Time of Pandemic Covid-19 throughout Industrial Revolution 4.0 as compared to Humane Leadership. International Journal of Social, Policy and Law, 1(1), 79-87

Hutagalung, L., Purwanto, A., \& Prasetya, A. B. (2020). The Five Leadership Style in Time of Pandemic Covid-19 throughout Industrial Revolution 4.0 as compared to Humane Leadership. International Journal of Social, Policy and Law, 1(1), 79-87. https://doi.org/10.8888/ijospl.v1i1.21

Kertas Posisi,Penanganan Wabah Pandemi Covid-19,Lembaga Bantuan Hukum Jakarta, 2020.

Matteo Antonio Sacco, The impact of the Covid-19 pandemic on domestic violence: The dark side of home isolation during quarantine, Medico-Legal Journal 2020, Vol. 88 https://doi.org/10.1177/0025817220930553

Media briefing, Tunda Pembahasan RUU Bermasalah di DPR:Negara Harus Fokus Pada Perlindnungan Kelompok Rentan Dalam Penangannan Covid-19,2020.
Muhammad Julian Syaputra , Agus Purwanto, Suhendra, Utomo, Romli Septiadi, Hayu Kartika, Rahardian Dimas Puja Kusuma, Moch Haris (2020) Does Smes Need Lean Six Sigma ? Anwer from Indonesian Smes during Pandemic Covid-19. Journal of Critical Reviews, 7 (19), 2331-2340. doi:10.31838/jcr.07.19.280

Mulyadi, Sudibjo, N., \& Bernarto, I. (2017). The Effect of Perceived Organizational Support, Work Engagement, and Job Satisfaction on Teacher's Performance at Xyz Middle and High School. International Journal of Economic Research, 14(13), 7-19.

Nonot Yuliantoro, Juliana, Vasco Goeltom, Innocentius Bernarto, Rudy Pramono, Agus Purwanto. (2020). Z Generation Satisfaction toward Food Street Culinary at the time of Covid 19 Pandemic. International Journal of Advanced Science and Technology, 29(04), 5014

Nonot Yuliantoro, Vasco Goeltom, Juliana, Innocentius Bernarto, Rudy Pramono, Agus Purwanto, (2020).Repurchase intention and word of mouth factors in the millennial generation against various brands of Boba drinks during the Covid 19 pandemic.African Journal of Hospitality, Tourism and Leisure, 8(2), 1-11

Nonot Yuliantoro, ${ }^{*}$ Vasco Goeltom, Juliana, Innocentius Bernarto (2019). Repurchase intention and word of mouth factors in the millennial generation against various brands of Boba drinks during the Covid 19 pandemic . African Journal of Hospitality, Tourism and Leisure, Volume 8 (2) - (2019).1-11

Purwanto, A. (2020). Studi Eksplorasi Dampak Work From Home ( WFH ) Terhadap Kinerja Guru Selama Pandemi Covid-19. EduPsyCouns: Journal of Education, Psychology and Counseling, 2(1), 92-100. https://doi.org/10.33366/jkn.v2i2.46

Purwanto, A. (2020). Studi Eksplorasi Dampak Work From Home ( WFH ) Terhadap Kinerja Guru Selama Pandemi Covid-19. EduPsyCouns: Journal of Education, Psychology and Counseling, 2(1), 92-100. https://doi.org/10.33366/jkn.v2i2.46

Purwanto, A., Pramono, R., Asbari, M., Hyun, C., Wijayanti, L., Putri, R., \& santoso, priyono. (2020). Studi Eksploratif Dampak Pandemi COVID-19 Terhadap Proses Pembelajaran Online di Sekolah Dasar. EduPsyCouns: Journal of Education, Psychology and Counseling, 2(1), 1-12.

Purwanto, A., Pramono, R., Asbari, M., Hyun, C., Wijayanti, L., Putri, R., \& santoso, priyono. (2020). Studi Eksploratif Dampak Pandemi COVID-19 Terhadap Proses Pembelajaran Online di Sekolah Dasar. EduPsyCouns: Journal of Education, Psychology and Counseling, 2(1), 1-12. Retrieved from https://ummaspul.e-journal.id/Edupsycouns/article/view/397

Purwanto, A., Pramono, R., Asbari, M., Hyun, C., Wijayanti, L., Putri, R., \& santoso, priyono. (2020). Studi Eksploratif Dampak Pandemi COVID-19 Terhadap Proses Pembelajaran Online di Sekolah Dasar. EduPsyCouns: Journal of Education, Psychology and Counseling, 2(1), 1-12. Retrieved from https://ummaspul.e-journal.id/Edupsycouns/article/view/397

Ratna Setyowati Putri, Agus Purwanto , Rudy Pramono, Masduki Asbari, Laksmi Mayesti Wijayanti, Choi Chi Hyun. (2020). Impact of the COVID-19 Pandemic on Online Home Learning: An Explorative Study of Primary Schools in Indonesia. International Journal of Advanced Science and Technology, 29(05), 4809 - 4818.

Riza (2020). Handling Corona Virus Pandemic In The Indonesian Political Context: A Grounded Theory Study. European Journal of Molecular \& Clinical Medicine, 7(8), 113-129.

Setyorini, I. (2020). Pandemi COVID-19 dan Online Learning: Apakah Berpengaruh Terhadap Proses Pembelajaran Pada Kurikulum 13?. Journal of Industrial Engineering \& Management Research, 1(1), 95-102. https://doi.org/10.7777/jiemar.v1i1.31

Suheny, E., Arum, M., Wandi, D., Rahmat, A., kurnianingsih, A., Haerani, A., Dasmaran, V., Taryanto, Adha, S. \& Purwanto, 
A. (2020) Develop Leadership Style Model for Indonesian SMEs Leaders During Covid-19 Pandemic. Systematic Reviews in Pharmacy, 11 (8), 576-586. doi:10.31838/srp.2020.8.82

Suprapti, S., Asbari, M., Cahyono, Y., \& Mufid, A. (2020). Leadership Style, Organizational Culture and Innovative Behavior on Public Health Center Performance during Pandemic Covid19. Journal of Industrial Engineering \& Management Research, 1(2), 76-88. https://doi.org/10.7777/jiemar.v1i2.42

Supriadi, O., Musthan, Z., Saodah, ., Nurjehan, R., Haryanti, Y. D., Marwal, M. R., Purwanto, A., Mufid, A., Yulianto, R. A., Farhan, M., Fitri, A. A., Fahlevi, M. \& Sumartiningsih, S. (2020) Did Transformational, Transactional Leadership Style and Organizational Learning Influence Innovation Capabilities of School Teachers during Covid-19 Pandemic?. Systematic Reviews in Pharmacy, 11 (9), 299-311. doi:10.31838/srp.2020.9.47

Suryaman, M., Cahyono, Y., Muliansyah, D., Bustani, O., Suryani, P., Fahlevi, M., Pramono, R., Purwanto, A., Purba, J. T.,
Munthe, A. P., Juliana, \& Harimurti, S. M. (2020) Covid-19 Pandemic and Home Online Learning System: Does it Affect the Quality of Pharmacy School Learning?. Systematic Reviews in Pharmacy, 11 (8), 524-530. doi:10.31838/srp.2020.8.74

Valeria Tullio, Psychological support and psychotherapy via digital devices in Covid-19 emergency time: Some critical issues, Medico-Legal Journal 2020, Vol. 88. https://doi.org/10.1177/0025817220926942

Word Health Ornanization, Violence And Injury Preven-tion www.who.int/violence_injury_prevention/violence/ en/ .

Yunita Noor Azizaha, Muhammad Khairul Rijalb, Rumainurc, Umi Nuriyatur Rohmahd, Syatria Adymas Pranajayae, Zulaecha Ngiuf, Abdul Mufidg, Agus Purwantoh, Dahlia Haliah Ma`ui. "Transformational or Transactional Leadership Style: Which Affects Work Satisfaction and Performance of Islamic University Lecturers During COVID-19 Pandemic?." Systematic Reviews in Pharmacy 11.7 (2020), 577-588. Print. doi:10.31838/srp.2020.7.82

\section{DOI: https://doi.org/10.6000/1929-4409.2021.10.63}

(C) 2021 Purba et al.; Licensee Lifescience Global.

This is an open access article licensed under the terms of the Creative Commons Attribution Non-Commercial License (http://creativecommons.org/licenses/by-nc/3.0/) which permits unrestricted, non-commercial use, distribution and reproduction in any medium, provided the work is properly cited. 